\title{
A harvestman (Arachnida: Opiliones) from the Early Devonian Rhynie cherts, Aberdeenshire, Scotland
}

\author{
Jason A. Dunlop, Lyall I. Anderson, Hans Kerp and Hagen Hass
}

\begin{abstract}
A harvestman (Arachnida: Opiliones) is described from the Early Devonian (Pragian) Rhynie cherts, Aberdeenshire, Scotland. Eophalangium sheari gen. et sp. nov. is the oldest known harvestman. The material includes both males and a female preserving, respectively, a cuticle-lined penis and ovipositor within the opisthosoma. Both these structures are of essentially modern appearance. The Rhynie fossils also show tracheae which are, again, very similar to those of living harvestmen. This is the oldest unequivocal record of arachnid tracheal respiration and indicates that $E$. sheari was terrestrial. An annulate, setose ovipositor in the female suggests that it can be excluded from the clades Dyspnoi and Laniatores, in which the ovipositor lacks such annulations. However, the penis shows evidence of two muscles, a feature of uncertain polarity seen in modern Troguloidea (Dyspnoi). The presence of median eyes and long legs excludes Cyphophthalmi, and thus, E. sheari is tentatively referred to the suborder Eupnoi. Therefore, this remarkable material is implicitly a crown-group harvestman and is one of the oldest known crown-group chelicerates. It also suggests an extraordinary degree of morphological stasis within the eupnoid line, with the Devonian forms differing little in gross morphology - and perhaps in reproductive behaviour - from their modern counterparts.
\end{abstract}

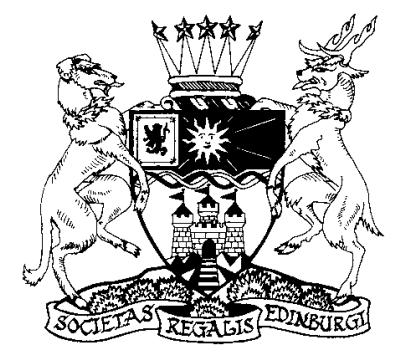

KEY WORDS: Arthropoda, Eupnoi, ovipositor, penis, phylogeny, tracheae, terrestrialisation.

Harvestmen (Arachnida: Opiliones) are arachnids in which the prosoma and opisthosoma are characteristically fused together with little visible tagmosis of the body. Other apomorphic features include prosomal repugnatorial glands, an arrangement of the sclerites such that the genital opening is thrust forward between the leg coxae, a penis (in the male) and ovipositor (in the female), and a single pair of tracheae opening on the genital segment (Martens 1978; Shultz 1990, 1998). In some ingroup harvestmen, the second pair of legs is longest and has a tactile, almost antenna-like function. While principally predatory on other arthropods, living harvestmen are - unusually for arachnids - to some extent omnivorous (Rühm 1926), and their diet can include dead arthropods, bird droppings, rotting fruit and other types of plant material. Some species specialise on snails. Most arachnids digest their prey preorally and need to filter the liquified food through the mouthparts. This implicitly terrestrial mode of feeding was developed early in arachnid history and was used by, for example, the Rhynie chert trigonotarbid arachnids (Dunlop 1994). By contrast, harvestmen can ingest solid food particles, a putative plesiomorphy which they share with xiphosurans (horseshoe crabs) and opilioacariform mites. Other plesiomorphic characters of harvestmen include chelate chelicerae formed from three articles and, perhaps, the absence of Malpighian tubules, a type of excretory organ adapted to life on land. The position of Opiliones within Arachnida remains contentious. The recent, and comprehensive, study of Giribet et al. (2002) found most support for placing harvestmen with scorpions, pseudoscorpions and solifuges in Shultz's (1990) clade Dromopoda, but concluded that current datasets are not decisive in resolving their affinities.

Approximately 5500 living species of harvestmen are known, traditionally divided among three quite distinct suborders (Shultz 1998; Giribet et al. 1999). Cythophthalmi are small, cryptic, rather mite-like animals with a wide, but somewhat localised, distribution (for an overview, see Giribet 2000). Laniatores is the most diverse group and includes larger, often quite bizarre-looking, brightly coloured and spiny animals with characteristically massive, sub-raptorial pedipalps (for a recent summary, see Kury 2003). Extant Laniatores occur predominantly in tropical zones of the southern hemisphere. Palpatores are the most widespread group in northern, temperate regions (e.g. Martens 1978), although recent analyses disagree about whether they are monophyletic (Shultz 1998) or paraphyletic (Giribet et al. 1999, 2002) (see Section 4). Nevertheless, all these models recognised two monophyletic palpatore taxa, traditionally assigned the rank of tribe, but raised to suborders by Giribet et al. (2002). Dyspnoi include the often cryptic troguloid harvestmen, some of which cover themselves with soil particles. The remaining suborder, Eupnoi, are the most familiar and commonly encountered living harvestmen in temperate regions, easily recognisable by their compact, oval bodies and long, slender legs. The present authors argue that their Rhynie fossils are probably eupnoids.

This paper describes three exceptionally preserved harvestmen from the Early Devonian Rhynie cherts of Aberdeenshire, Scotland. Two of these fossils were briefly described by Dunlop et al. (2003) and represent the oldest record of Opiliones. Like many Rhynie arthropods (Hirst 1923; Hirst \& Maulik 1926; Scourfield 1926; Claridge \& Lyon 1961; Anderson \& Trewin 2003), they include remarkable details of the internal and external anatomy. The tracheae described here are the oldest unequivocal evidence for arachnid tracheal respiration and imply that these harvestmen were fully terrestrial (see Section 5.2). When compared to extant taxa, we can sex the fossils based on their preserved genitalia. These structures also allow behavioural inferences about these Early Devonian arachnids. 


\section{Other fossil harvestmen}

In spite of their Recent diversity, fossil harvestmen are rare. The oldest previous record is an unnamed, long-legged Scottish specimen from the Lower Carboniferous of East Kirkton (Wood et al. 1985). Four Coal Measures species have been described: two from Commentry in France (Thevenin 1901) and two from Mazon Creek in the USA (Petrunkevitch 1913). As noted by Beall (1997), at least one Mazon Creek species is a poorly preserved phalangiotarbid (an extinct order), and fossils from this locality referred to another extinct arachnid order, Kustarachnida, are in fact misidentified harvestmen. Redescriptions would be welcome, but most of these Palaeozoic fossils provisionally resemble eupnoids, while one of the Commentry species is probably a dyspnoid. A putative harvestman from the Lower Permian of Germany is a misidentified plant fragment (Rößler et al. 2003). A Jurassic 'harvestman' described from Solnhofen in Germany is a crinoid (Petrunkevitch 1955), however unequivocal, but unnamed, Mesozoic palpatore harvestmen have been reported from the Lower Cretaceous of Australia (Jell \& Duncan 1986) and the Upper Cretaceous of Lebanon (Roger 1946). Tertiary harvestmen mostly comprise numerous Baltic and Dominican amber inclusions and shale fossils from Florissant in Colorado; for example, see Cokendolpher (1986 and references therein) for details and Starega (2002) for a recent revision of the Baltic amber fauna. Most of these Tertiary fossils are eupnoids and dyspnoids. Fossil Laniatores are somewhat rarer, but have been recorded from both Baltic and Dominican amber (e.g. Cokendolpher \& Poinar 1998). The first fossil cyphophthalmid has recently been discovered in the German Bitterfeld amber (Dunlop \& Giribet 2003) and most of the Tertiary amber harvestmen can be referred to living genera.

\section{Materials and methods}

The Rhynie chert harvestmen were discovered by one of the present authors (H.H.) in sections prepared in the palaeobotany research group of the Westfälische WilhelmsUniversität, Münster, Germany. Specimens are cited as PBM (for Paläobotanik Münster). The material described in this paper is housed here as part of the slide series 3501-3511. All three specimens are in relatively thick (c. $0.5-0.6 \mathrm{~mm}$ ), polished sections mounted on glass slides. They were examined, photographed and then repolished in order to improve translucency to transmitted light and to concentrate on specific morphological details. A small number of additional slides taken from the same sequence contain longitudinal sections through the extreme lateral parts of the body of the holotype, but show no additional features and are not figured here. Specimens were studied using both a steromicroscope and, for higher magnification (including oil immersion), a Wild compound microscope. The Rhynie material was photographed using either incident (Figs 1, 3, 7a) or transmitted (Figs 5, 7b) white light on panchromatic 25150 film. Drawings were prepared with the aid of a camera lucida. Fossils were compared to extensive collections of extant opilionids in the Museum für Naturkunde, Berlin, Germany. Morphological terminology mostly follows Shultz (2000).

\subsection{Geological setting and preservation}

The Rhynie and Windyfield cherts were deposited in an area of predominantly fluvial and lacustrine deposition through the action of localised terrestrial hot springs (Rice et al. 2002). The erupted hot-spring waters formed sinters around well-defined vents and supplied cool water pools in the vicinity with elevated levels of dissolved silica. Through interaction with organic detritus, these pools, rich in filamentous algal and cyanobacterial growth, provided ideal sites of preservation for the aquatic and terrestrial floras and faunas in the immediate area of the hot springs (see also Anderson \& Trewin 2003). Further details of the geological setting, dating (Pragian) and the preservational environment at Rhynie can be found in Rice et al. (2002) and references therein.

2.1.1. Palaeoenvironment. All three specimens described in the present paper were found contained within a 5-6-cm-thick bed of massive, white chert within a single block. The bed itself contains a monospecific, in situ flora of mature Aglaophyton plants, bearing numerous terminal sporangia which are either empty or partially filled with spores. The Aglaophyton axes show excellent preservation. Typically, all cells and tissues are preserved, indicating massive and rapid silicification. All aerial axes of Aglaophyton are oriented parallel to each other at an angle of about $50^{\circ}$ to the vertical plane, suggesting a strong and directional (?flooding) event prior to silicification. The white bed overlies a chert-cemented sandstone, rich in compressed and decomposed axes of land plants. Several of the Aglaophyton axes of the white chert bed can be traced into the underlying sandstone, suggesting that the sandstone represents the former soil and the Aglaophyton of the chert bed its surface flora. The white chert is directly overlain by a second massive chert bed, up to $10 \mathrm{~cm}$ thick. This second chert also contains a monospecific, in situ flora of Aglaophyton, with excellent preservation in parts. Here, the aerial axes of Aglaophyton occur in an irregular orientation in this second chert bed. No organic connection was found between the Aglaophyton plants of both beds, indicating that the lower chert bed was silicified prior to being colonised by a new Aglaophyton flora.

2.1.2. Organic content. The white chert bed containing the harvestmen shows some degree of vertical differentiation. In the basal $45-50 \mathrm{~mm}$, the matrix between the Aglaophyton axes is mostly clear and contains numerous pieces of Lepidocaris cuticle (eggshells, and larval and adult specimens), as well as some organic detritus, mostly from dissolved coprolites. In addition, a few incomplete remnants of trigonotarbid arachnids occur. In the uppermost $5-15 \mathrm{~mm}$, an increasingly dense mat of fungal hyphae fills the matrix, enveloping the axes and sporangia of the Aglaophyton. The three harvestmen in the present study were found around the lower boundary of this fungal mat. Within the fungal mat, numerous germinating spores and young gametophytes of Aglaophyton occur, either dispersed or in dense patches of c. 50-100 specimens.

The aquatic microflora of the whole chert bed-including the fungal mat at the top - is represented only by aquatic fungi. The algae Palaeonitella and cyanobacteria are completely lacking. Within the fungal mat, well-preserved coprolites occur. Their content varies from pure Aglaophyton spores to mixed remnants of land plant tissues. Judging from the different dimensions, forms and digested contents, more than half a dozen different types of coprolites occur. Within the fungal mat, several bodies of young to adult trigonotarbids were found ranging from a few millimetres up to c. $15 \mathrm{~mm}$. More trigonotarbids were found within the sporangia. Also in the sporangia of Aglaophyton, and in decomposing spaces within the axes of these plants, hundreds of mites and their coprolites are preserved, often in dense colonies. At the base of some empty sporangia, dense masses of intertwined mite layers may occur, hinting that the trigonotarbids may have been feeding on them. Within the intercellular spaces of about $10-15 \%$ of all Aglaophyton axes in this chert bed, hundreds of nematodes (all life stages and both sexes) were found. Preservation is excellent and includes muscles, as well as digestive and reproductive organs. Generally, in this chert bed with the 
harvestmen, a greater part of the Rhynie biotope seems to have been preserved in an excellent condition by a strong flooding event and successive rapid silicification.

2.1.3. Preservation. PBM 3503 (the female and holotype designate) is associated with the typical microcoprolite-rich mulm texture. However, in this instance, the texture is patchy and confined to a region lying above and to the left of the abdomen. Generally, this is typical of the facies in which trigonotarbid arachnids are routinely discovered (see Section 2.1.2). Stands of upright plants and layers of plant litter engulfed in silica-rich waters formed mesh networks in which these terrestrial arachnids were held. A translucent, milky chert surrounds and preserves the tracheal system (see Section 3.1.5). A thin layer of organic mulm coating the inner surface of the abdomen of this fossil probably represents minor decomposition and degradation of the body fluids. The body cavity also demonstrates the presence of botryoidal silica growth indicating that the cavity was empty prior to silicification. Perhaps the organic tissues were macerated by hot, alkaline water? The milky chert comprising the internal fill of this fossil is characteristic of many of the arthropods discovered so far. It indicates a separate phase and environment of infill and silicification to that of the matrix lying outside the body walls. PBM 3511 (the incomplete paratype male) is preserved under similar conditions.

By contrast, a relatively homogenous, translucent chert encloses specimen PBM 3509 (the more complete paratype male). This chert texture is characteristic of the facies that typically contains Lepidocaris, the euthycarcinoid Heterocrania (c.f. Anderson \& Trewin 2003) and the charophyte Palaeonitella (cf. Kelman et al. 2004). The harvestmen are clearly terrestrial (see Section 5.2), and to this end, PBM 3509 obviously represents an accidental inclusion in an otherwise aquatic depositional setting.

2.1.4. Recent contaminants? The extraordinary quality of preservation at Rhynie, coupled with its great age and the apparent modernity of some of the arthropods, led Crowson (1985) to suggest that some elements of the Rhynie chert fauna, in particular the mites and collembolans, might have been Recent contaminants incorporated into the chert through secondary silicification. This harvestman is also surprisingly modern in appearance (see Section 3), but the present authors can refute Crowson's hypothesis on the following grounds. First, the circumstances and processes which gave rise to the bedded cherts at Rhynie were relatively (geologically) shortlived. The opportunity and mechanism for re-mobilising silica from the crypto-crystalline chert and depositing it to include contaminants (Recent or otherwise) has not been available in the area since the Early Devonian. Secondly, as well as 'modern' arthropods, the Rhynie and Windyfield cherts contain extinct arthropod groups which are quite different to those living today; for example, trigonotarbids and euthycarcinoids (Hirst 1923; Anderson \& Trewin 2003). The micro-textures enclosing, and the taphonomic processes associated with, the extinct arthropods can be demonstrated to be identical to those in the 'modern'-looking group of potential contaminants. Finally, prior to 1992, samples of chert containing arthropods were only recovered as float in the soil overlying the sub-crop and by excavation of shallow trenches. This could be argued as a potential source of Recent contamination. An intensive drilling programme carried out by the University of Aberdeen in 1997 provided bedded cherts from drill core sections of Rhynie chert which contained fossil arthropod material from well below the weathered profile. Thus, like Greenslade (1988), the present authors reject the contamination hypothesis.

\section{Morphological interpretation}

The Rhynie harvestman is known from three specimens. PBM 3501-3506 is the largest (total length c. $6 \mathrm{~mm}$ ) and the described slide (3503, Figs 1-4) is a lateral section through the entire body close to the midline. PBM 3509 (Figs 5-6) is a smaller specimen (opisthosomal length c. $2 \mathrm{~mm}$ ) preserved in ventral view in which the actual ventral surface of the opisthosoma is missing, revealing internal features. It is associated with legs, some of which seem to be disarticulated from the body. PBM 3511 (Figs 7-8) is known only from isolated mouthparts, coxae and part of the opisthosoma. All three were prepared from the same block of chert (see Section 2.1.1) and a number of other fragments, mostly parts of elongate limbs, also occur among this material.

\subsection{PBM 3503 (female)}

3.1.1. Carapace and eyes. In comparison to extant eupnoid harvestmen (e.g. Shultz 2000), the prosomal dorsal shield (or carapace) is tentatively interpreted here as being composed of three sclerites, a longer propeltidium followed by two shorter elements, the mesopeltidium and metapeltidium (Figs 1a, 2a). The exact boundary between the prosoma and opisthosoma is difficult to confirm without a dorsal view, and it is possible that the metapeltidium could be the first opisthosomal tergite. The present authors interpret the raised structure on the midline at the front of the propeltidium as the optic tubercle, but individual eye lenses cannot be resolved in transverse section. In extant harvestmen, the eyes are typically on the lateral sides of the tubercle and stare outwards. Below this optic tubercle, the carapace curves round on itself to form a narrow doublure. The propeltidium is flat and smooth, but the meso- and metapeltidium rise successively and, with the anterior part of the opisthosoma, they give the animal a distinctly 'hunchbacked' appearance. A few extant harvestmen show a similar rise at the back of the carapace (e.g. Roewer 1923, fig. 1058).

3.1.2. Mouthparts and coxae. One of the paired chelicerae emerges below the doublure of the propeltidium and at least two articles are clearly preserved (Figs 1a \& 2a). The most proximal article (the coxa sensu Shultz 2000) is short and projects anteriorly. The succeeding deutomerite is longer, doubles back and is directed postero-venterally. This is entirely consistent with extant harvestmen. The living taxa show considerable variability in the size, shape and proportions of the chelicerae (e.g. Roewer 1923), and those in the Rhynie fossil are towards the small end of the scale. Details of morphology are lacking. Adjacent to the preserved chelicera is a proximal article (?femur) of a pedipalp, again without details. Below the chelicerae, there are two anteriorly projecting sclerites. These may represent the labrum and/or one or more of the three pairs of coxapopyhses which derive from the coxa of the pedipalps and the first two pairs of walking legs, which act as mouth lips in living harvestmen, forming the floor and walls of a preoral cavity, or stomotheca. Without a ventral view, their precise affinities are difficult to resolve. The proximal regions of at least two coxae are preserved and, turning the section over, these are seen to expand distally. In extant taxa, the leg coxae tend to turn upwards towards the distal end, but this is difficult to assess in these sections.

3.1.3. Opisthosoma. The opisthosoma is deep and compact, about the same length as the prosoma. There is no clear tagmosis between the two major parts of the body (see Section 3.1.1). Dorsally, there is a series of undulations (Figs 1a \& 2a) suggesting at least five weakly defined tergites. This is consistent with many living taxa in which segmentation is typically indistinct and sometimes only betrayed by subtle coloration 

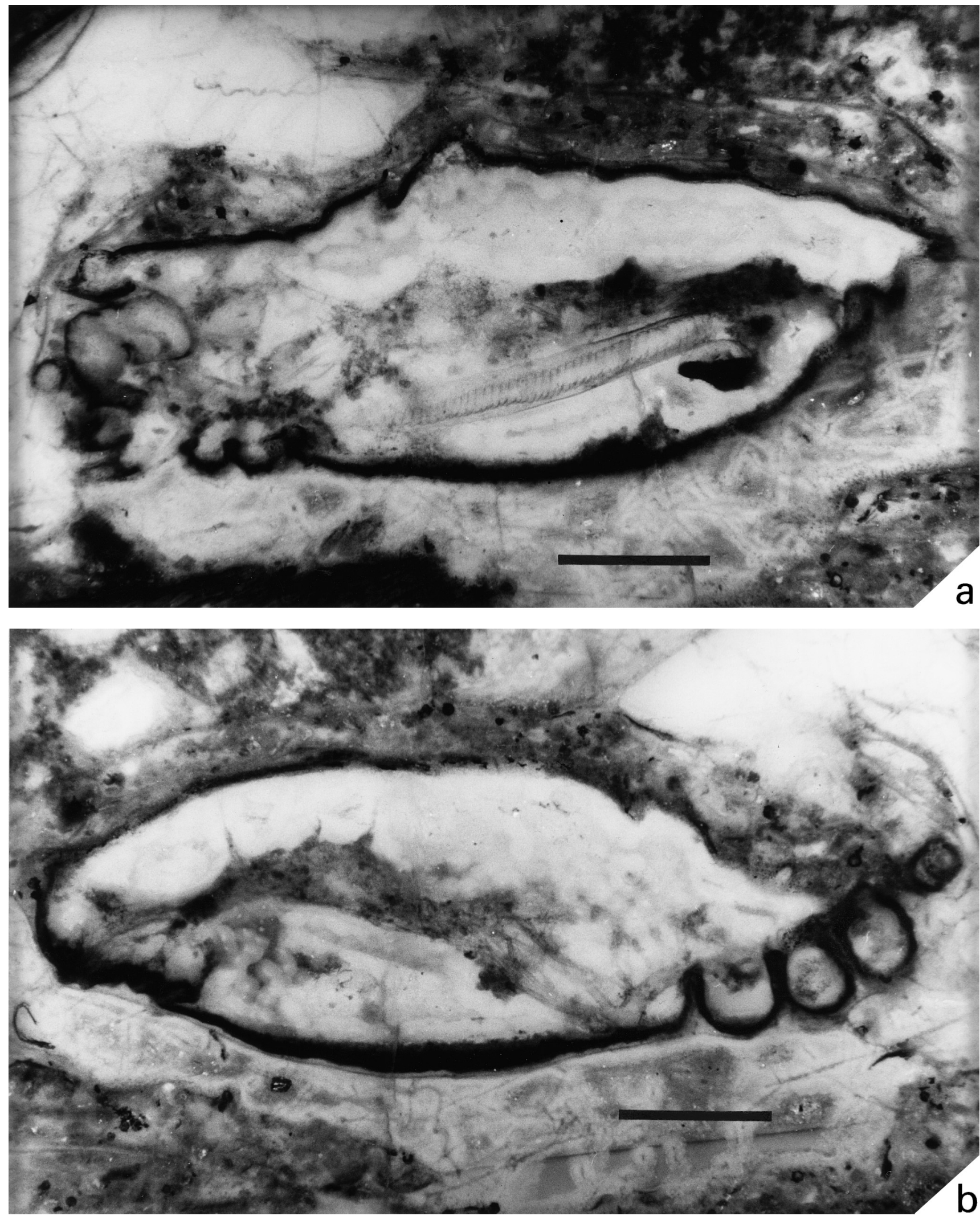

Figure 1 Eophalangium sheari gen. et sp. nov. Holotype (female), slide no. 3503. A harvestman (Opiliones) from the Rhynie chert, Aberdeenshire, Scotland. Early Devonian (Pragian). (a) Lateral section close to the midline showing the outline of the compact body. Note the mouthparts, anteriorly positioned optic tubercle and distinctly 'hunchbacked' appearance. The elongate internal structure is the ovipositor; (b) Reverse side of same specimen at a more lateral plane showing a dark internal gut trace in the opisthosoma and the branching tracheal system originating just behind the last leg coxa. The structures are labelled in Fig. 2 (scale bars $=1 \mathrm{~mm}$ )

differences or muscle apodemes (Shultz 2000). Ventrally, the cuticle is smooth and does not show division into sternites. Extant harvestmen are sometimes quite heavily armoured, but there is no ornament of spines or tubercles anywhere on the body surface of the fossil. There is some suggestion of a swelling around the anal region, but individual scleriteswhich can be quite complex around the anus in living taxaare not preserved. 

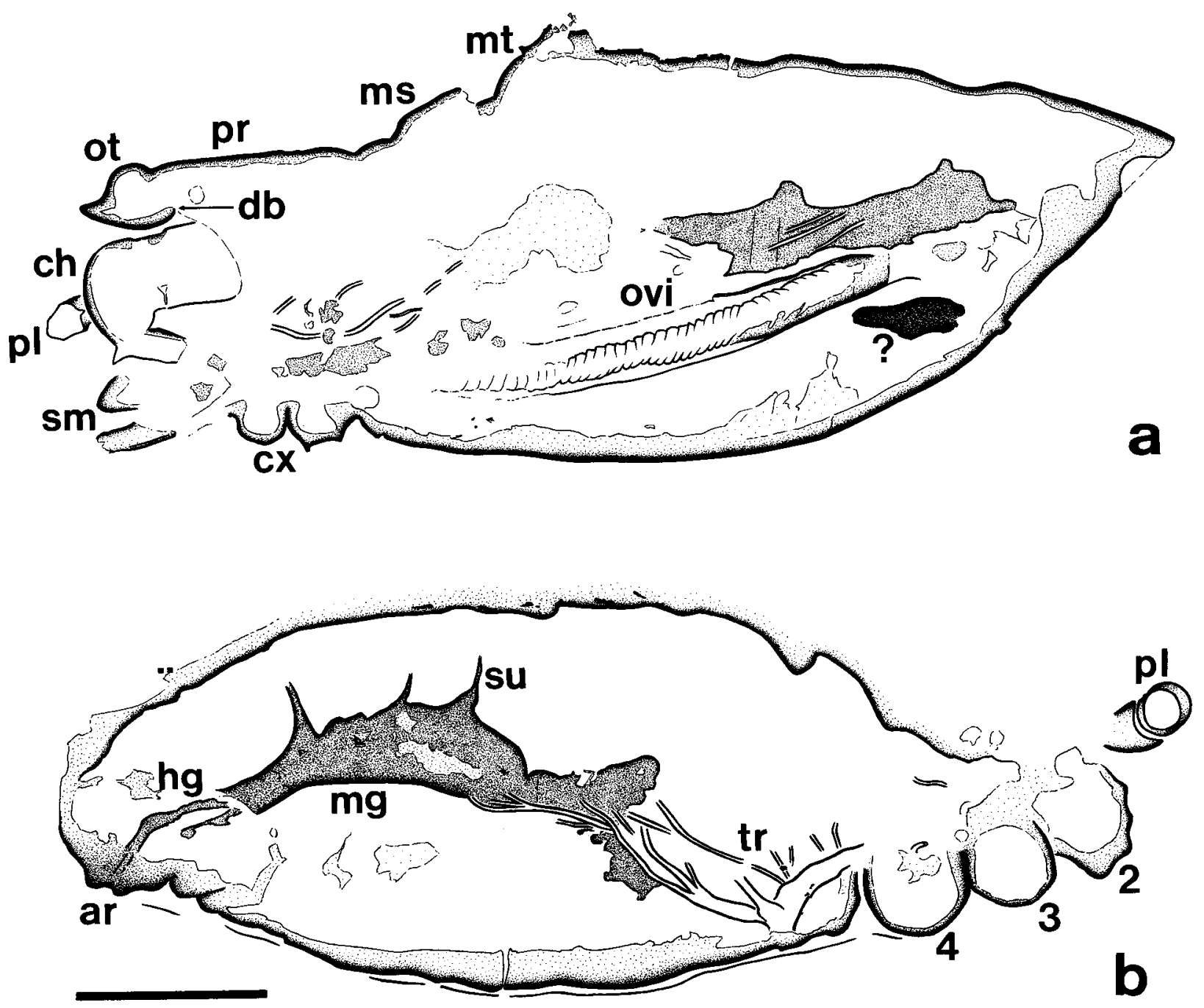

Figure 2 Camera lucida drawing of the specimen shown in Fig. 1: (a) midline section; and (b) more lateral section. Abbreviations: (ar) anal region; (ch) chelicera; (cx) coxae; (db) carapace doublure; (hg) hindgut; (mg) midgut; (ms) mesopeltidium; (mt) metapeltidium; (ot) optic tubercle; (ovi) ovipositor; (pl) pedipalp; (pr) propeltidium; (sm) elements of stomatheca; (su) suspensory elements; (tr) tracheae; (2-4) leg numbers; and (?) unidentified element, perhaps part of the ovary (scale bar $=1 \mathrm{~mm}$ ).

3.1.4. Ovipositor. Within the opisthosoma, there is an unmistakable internal structure (Figs 1a \& 2a) originating in the posterior region, more or less in the middle of the specimen on the dorso-ventral axis. This structure then makes a shallow curve down towards the ventral surface such that its distal part, the tip of which is not preserved, lies close to the ventral surface and is oriented towards the coxo-sternal region. Midway along its length, it becomes apparent that this is an annulate organ lying within a sheath. It is unquestionably an ovipositor since it corresponds precisely with an unextended ovipositor in life position in living eupnoid harvestmen in both its annulate structure and its position within the opisthosoma (Kaestner 1941, figs 424, 458; Peters 1966b, figs 6-10; Martens et al. 1981, fig. 41). During oviposition, this long, flexible structure is extended out through the gonopore, probably under haeomolymph pressure (Shultz 2000) and inserted into the substrate. Therefore, PBM 3501-3506 is an adult female.

Seen under higher magnification (Figs 3a, 4a), the ovipositor is a membranous tube, approximately $200 \mu \mathrm{m}$ in diameter with a series of folds along its length forming the annulations. Details of these c. $50-\mu \mathrm{m}$-long annulations can clearly be seen, as can short setae which emerge sporadically along its length, predominantly on the dorsal surface (Fig. 3b). Their essentially dorso- and ventrolateral position in Recent harvestmen was nicely illustrated by Peters (1996b, fig. 8), who described them as sensory hairs, presumably helping the ovipositor to 'feel' its way into the substrate. The entire ovipositor in the fossil is enclosed within a thin, cuticular sheath. In comparison with extant taxa (Shultz 2000), this could be either the inner sheath and/or the outer sheath of the ovipositor. Only one layer is clearly preserved in the fossil, and since the inner sheath in extant taxa is noted as being thin and membranous (Shultz 2000), the present authors suspect this is the outer sheath. In those extant harvestmen with an annulate ovipositor, the tip is bifurcate, but this distal region is obscured in the present material.

The identity of the dark, amorphous structure just beneath the base of the ovipositor in the fossil (Figs 1a, 2a) is uncertain. It does not appear to be part of the gut (see Section 3.1.6). Its position is consistent with it being part of the ovary (e.g. Kaestner 1933, fig. 10), although it is unusual for soft parts to be preserved in Rhynie fossils; normally, only cuticle-lined structures are present.

3.1.5. Tracheae. The reverse side of PBM 3503 is at a more lateral plane of section than the front side described above and reveals a series of cuticular tubes within the body cavity (Figs $1 b, 2 b)$. Further polishing of the specimen revealed the extent of these tubes more clearly. They radiate from what appears to 

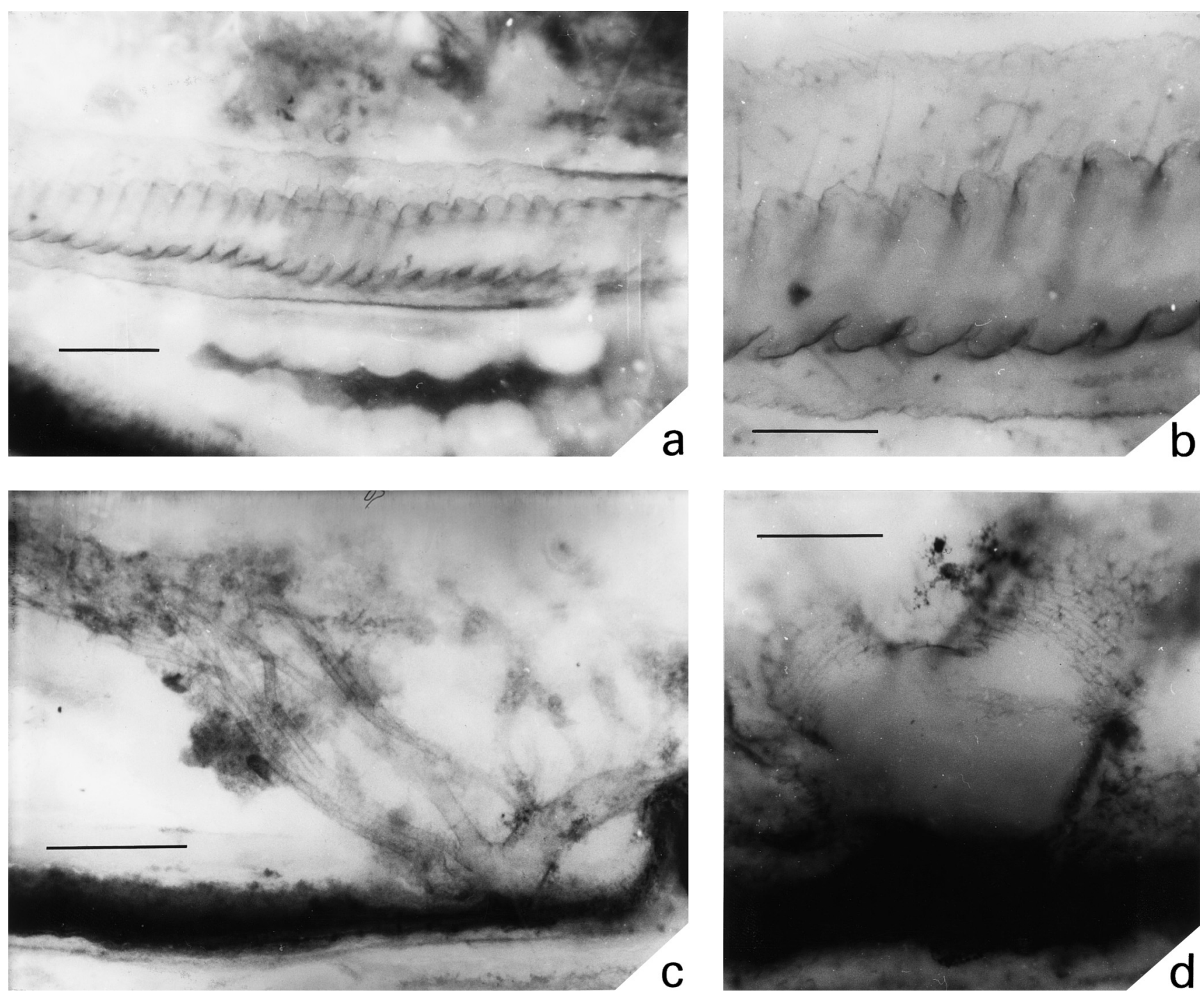

Figure 3 Eophalangium sheari gen. et sp. nov. Holotype (female), slide no. 3503. Ovipositor and tracheae. (a) Annulate ovipositor lying within its cuticular sheath (scale $b a r=200 \mu \mathrm{m}$ ); (b) Detail of the annulations with the predominately dorsal setae (scale bar $=100 \mu \mathrm{m}$ ); (c) Overview of the branching tracheae within the anterior abdomen. The large stem trachea runs into the prosoma, while the secondary tracheae branch within the opisthosoma runs towards the midgut (scale bar $=400 \mu \mathrm{m}$ ); (d) Detail of the proximal junction between the stem trachea and one of the secondary tracheae showing the ring-like thickenings of the cuticle on both branches. The structures are labelled in Fig. 4 (scale bar $=100 \mu \mathrm{m}$ ).

be a single (unresolvable) point of origin, just behind the fourth leg coxa. Compared with extant harvestmen, they are undoubtedly tracheae and represent the oldest record of arachnid tracheal respiration (see Section 5.2). In detail (Figs 3c, 4b), the expected atrium immediately within the spiracle is not preserved, but the tracheae themselves have a proximal branching point from which five main tubes arise. The largest of these curves anteriorly towards the prosoma, the other four run postero-dorsally within the opisthosoma. A number of annulations surround the base of at least two of these tracheae (Fig. 3d) and, presumably, have some sort of strengthening function. From these major elements, a number of increasingly smaller tubes branch off, and over 20 individual branches can be resolved (Fig. 4b). In the plane of section, there is a clear trend for the branches of the four smaller tracheae to surround the ventral region of the midgut (see Section 3.1.6).

An almost identical morphology has been described in Recent eupnoids and dyspnoids (Kaestner 1933, figs 18-19; Höfer et al. 2000, fig. 2). The large branch primarily serving the prosoma has been referred to as the stem trachea and the corresponding smaller branches coming off it and serving the opisthosoma represent the secondary tracheae. The Rhynie fossil effectively preserves a modern harvestman respiratory system, although some fine details, such as a filter system across the spiracle in living harvestmen (Höfer et al. 2000), remain equivocal.

3.1.6. Gut trace. The final internal structure of note is the dark gut trace. Its morphology is best seen on the reverse side along with the tracheae (Figs 1b, 2b). The gut is a dark, curving, sac-like structure, narrower and less well defined anteriorly, but widening in the posterior half of the opisthosoma. Based on illustrations in Kaestner (1933) and Peters (1996a), extant taxa also show a division of the rather broad midgut into an anterior and posterior part. This posterior part in the fossil shows three dorsal projections which could be diverticula, but which also look like some sort of suspensory element that helps to hold the gut in place. Posteriorly, there is a narrow hindgut leading towards the anal region.

Interestingly, Rhynie arthropods do not usually preserve a gut trace since the midgut region lacks a cuticular lining and it is this cuticle which is preserved in, say, the internal tracheae or genitalia. The enigmatic Leverhulmia mariae Anderson \& Trewin, 2003 (described as a myriapod, but which may, in fact, be a hexapod, S. Fayers, pers. comm.) also shows a gut infill of 

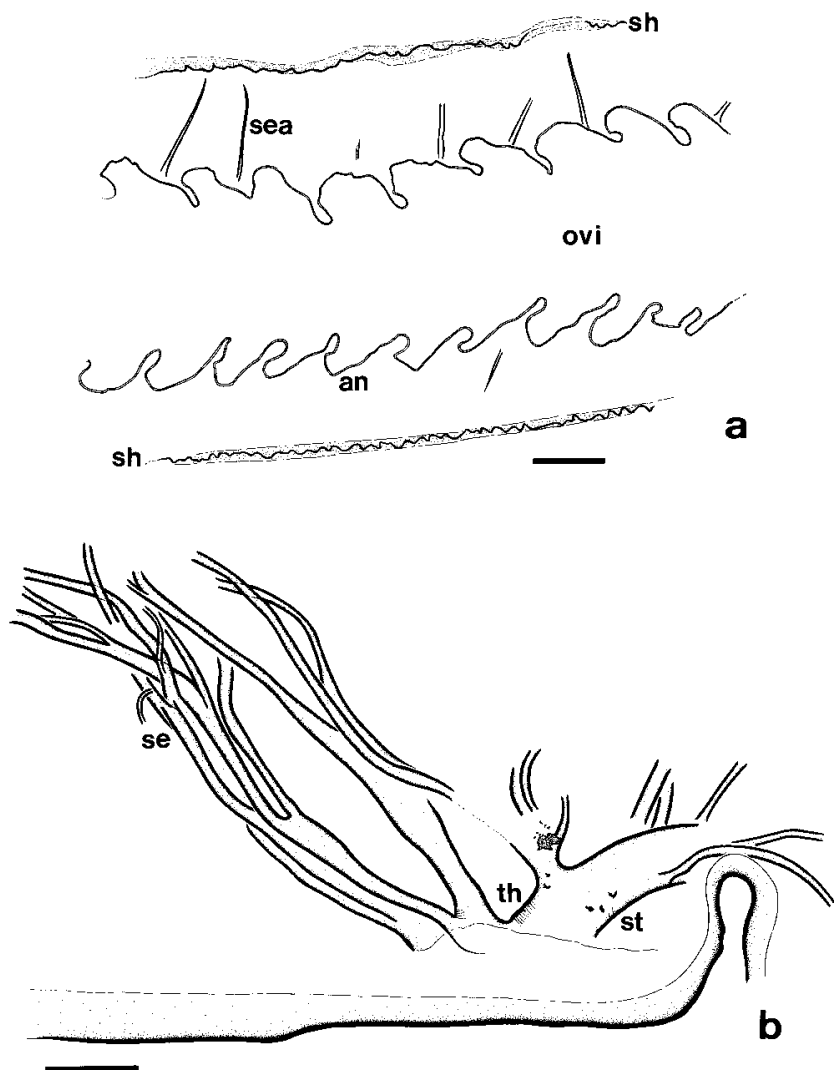

Figure 4 Camera lucida drawings of the specimen shown in Fig. 3: (a) ovipositor (scale bar $=50 \mu \mathrm{m})$; (b) trachea (scale bar $=200 \mu \mathrm{m})$. Abbreviations: (an) individual annulation of ovipositor; (ovi) ovipositor; (se) secondary trachea; (sea) seta; (sh) ovipositor sheath; (st) stem trachea; and (th) thickening around base of tracheal tube.

spores and other plant tissue, but the gut wall itself is not preserved, rather only the plant cuticles inside it. The present authors might speculate that their fossil preserves a gut trace as a consequence of: (1) the absence of preoral digestion, meaning that both cuticles and soft tissues from its prey are ingested; and/or (2) its omnivorous diet including a significant proportion of robust cuticle from plant remains. The predatory trigonotarbid arachnids with preoral digestion filtering out hard parts of cuticle never preserve a gut trace at Rhynie. Individual spores or identifiable cuticles cannot be resolved within the harvestman gut.

\subsection{PBM 3509 (first male)}

3.2.1. Opisthosoma. The specimen is preserved in quite a thin section and the opisthosoma is only preserved in outline with no indication of segmentation (Figs 5a, 6a). It is essentially oval, but narrows anteriorly between the leg coxae (Figs $5 c \& 6 c)$. Here there is an oval ring of cuticle that, in comparison to extant taxa, the present authors interpret as part of the genital opening or gonopore. Quite how this cuticular ring relates to the gonopore opening beneath the so-called operculum in most extant taxa remains unclear (W. Shear, pers. comm.). A fully open gonopore without a corresponding operculum is a plesiomorphic feature seen only in cyphophthalmids. We lack a clear ventral view, but perhaps such a ring-like gonopore was retained in the Rhynie species? In any case, its anterior position, thrust up between the leg coxae, is an autapomorphic harvestman feature (see Section 4).

3.2.2. Limbs. This specimen shows the most complete limb series. The legs consist proximally of a narrow, subtriangular coxa (Figs 5c \& 6c) and a short trochanter that is approximately as long as wide. The coxae bear rows of darker, granule-like projections. Similar structures can be seen in some extant palpatore harvestmen (e.g. Rambla 1975, fig. 31) where they can interlock like teeth with each other and increase the general immovability of the coxo-sternal region. The femur in the fossil is long, slightly longer than the opisthosoma, and widens at the distal end. The patella is very short and the adjacent tibia is another extremely elongate podomere, even more slender than the femur (Figs 5a, b \& 6a, b). If the present authors' assignments are correct, the tibia is at least twice as long as the opisthosoma in one limb. Examination of one tibia in detail (Figs 5b \& 6b) failed to reveal any tracheal openings: an autapomorphy of extant phalangiid families (see Section 4). The more distal podomeres (i.e. the basitarus and tarsus) are not clearly preserved. These long, slender, uniramous limbs are highly characteristic for harvestmen and have not been seen in any of the Rhynie arthropods described previously (e.g. Hirst 1923; Anderson \& Trewin 2003). Leg length varies between species of modern 'palpatore' harvestmen, but it is clear from the relative lengths of the podomeres preserved that we are dealing here with a Devonian animal which was a fairly modern-looking, long-legged species (Figs 5a \& 6a), certainly similar in overall habitus to living, 'daddy-long-legs' harvestmen. It is also similar to the East Kirkton specimen described by Wood et al. (1985).

3.2.3. Tracheae. The fossil contains two elongate, pale structures within the body cavity (Figs $5 \mathrm{c} \& 6 \mathrm{c}$ ), originating close to the posterior margin of coxa IV. The one on the left is better preserved than the one on the right. Again, the present authors interpret these as tracheae and the apparent presence of only one pair supports the referral of these Rhynie fossils to Opiliones (see Section 4.0). In comparison to the female, only a single pair of branches are preserved and no further ramifications from them are evident. The two tracheae converge towards the midline in the posterior half of the opisthosoma. Considering the plane of section, the authors presume these to be secondary tracheae, the more dorsal stem tracheae having been lost during preparation.

3.2.4. Penis. In addition to the tracheae, PBM 3509 preserves a further, median structure within the body cavity (Figs $5 \mathrm{c} \& 6 \mathrm{c})$. It is a smooth, cuticular rod that tapers distally to a point near the gonopore. The present authors interpret this as a penis, and thus, the specimen is implicitly male. As with the ovipositor, a similar structure is seen in this position in the males of extant harvestmen (Kaestner 1941, fig. 467; Shultz 2000, fig. 7c) and is extended through the gonopore during copulation. The authors' reasons for interpreting it as a penis are (1) the lack of annulation seen in unequivocal eupnoid ovipositors (see Section 3.1.4) and (2) the absence of a typically bifurcate ovipositor tip (e.g. Martens et al. 1981).

As in extant harvestmen, the Rhynie penis (Figs 5d \& 6d) consists mostly of a cuticular shaft. The present authors suggest that a pair of dark lines towards the lateral sides of the shaft are the tendons of the penis musculature. This is potentially significant since it implies the presence of two muscles which, according to the scheme of Martens (1976), occur only in the extant superfamily Troguloidea. By comparison, cyphophthalmids have three muscles, phalangioids have only one muscle and Laniatores have a hydraulic penis completely lacking musculature (see also Giribet et al. 2002, fig. 11). The shaft terminates in, and can flex against (Shultz 2000), a distal glans that, in those taxa with penis muscles, is moved by the tendons attaching to the base. The glans itself is a bulbous, ovate structure that bears a few short setae in the fossil (Figs 5e $\& 6 \mathrm{~d})$. The glans then merges into a tapering, distal stylus that lacks further external ornament, but contains hints of a tube-like lumen (Fig. 5d). Overall, the Rhynie penis is remarkably similar in gross morphology to the penis of the extant 

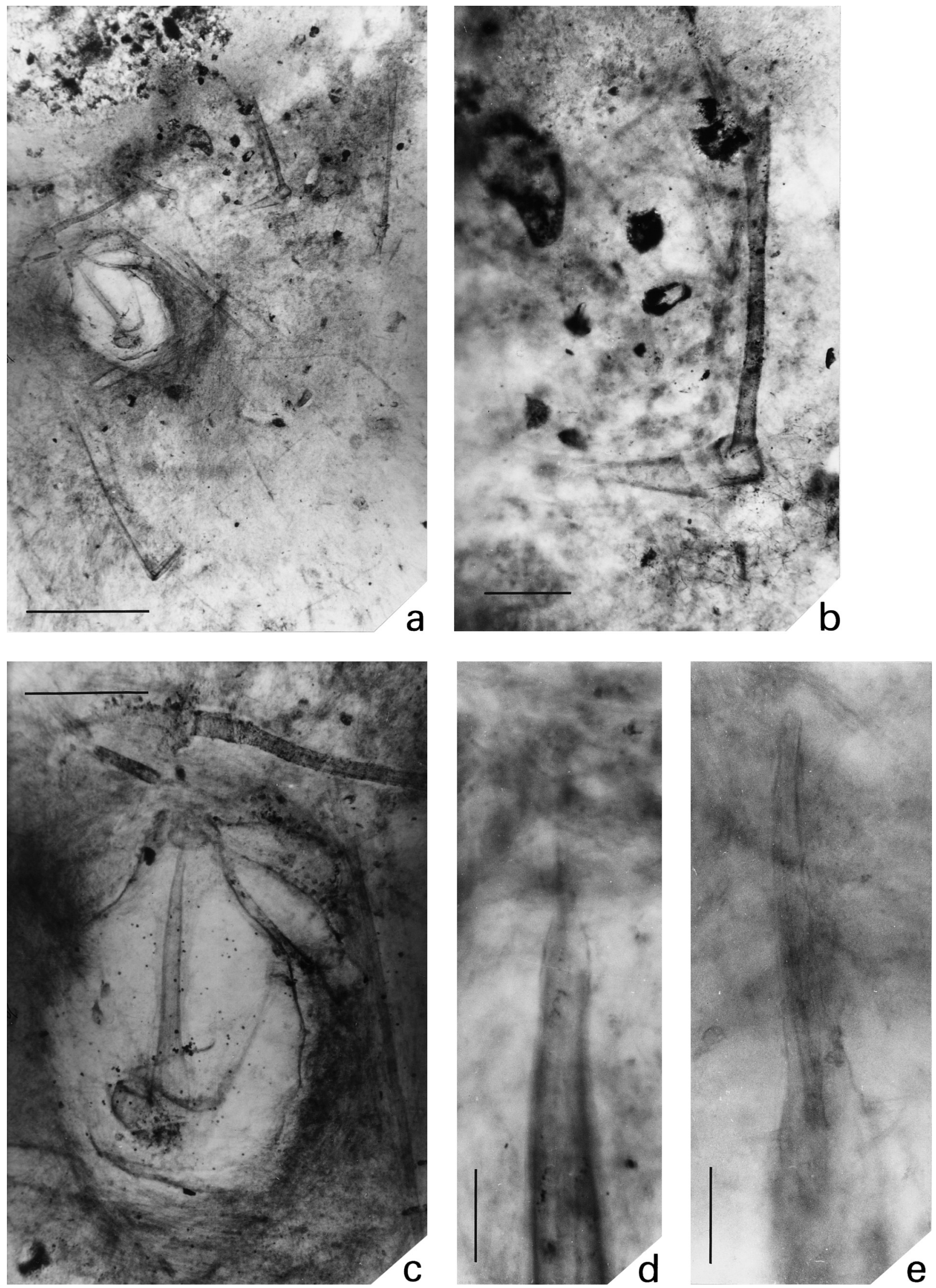

Figure 5 Eophalangium sheari gen. et sp. nov. Paratype 1 (male), slide no. 3509, from the same locality as the holotype. (a) Overview showing a small body surrounded by long, slender legs (scale bar $=1 \mathrm{~mm}$ ); (b) Detail of the femur-patella-tibia articulation. No evidence for tibial spiracles preserved (scale bar $=200 \mu \mathrm{m}$ ); (c) Detail of opisthosoma in essentially ventral view with sternites shorn away to reveal internal structures (e.g. tracheae and penis). Note the rounded gonopore at the anterior end and at least two pairs of coxae bearing rows of granular tubercles (scale bar $=300 \mu \mathrm{m}$ ); (d) Penis showing a tapering shaft with paired dark lateral bands, possibly muscle tendons, articulating against distal glans (scale bar $=50 \mu \mathrm{m}$ ); (e) Detail of ovate glans merging into a slender stylus tip. Note the setae emerging from glans (scale bar $=20 \mu \mathrm{m}$ ). 

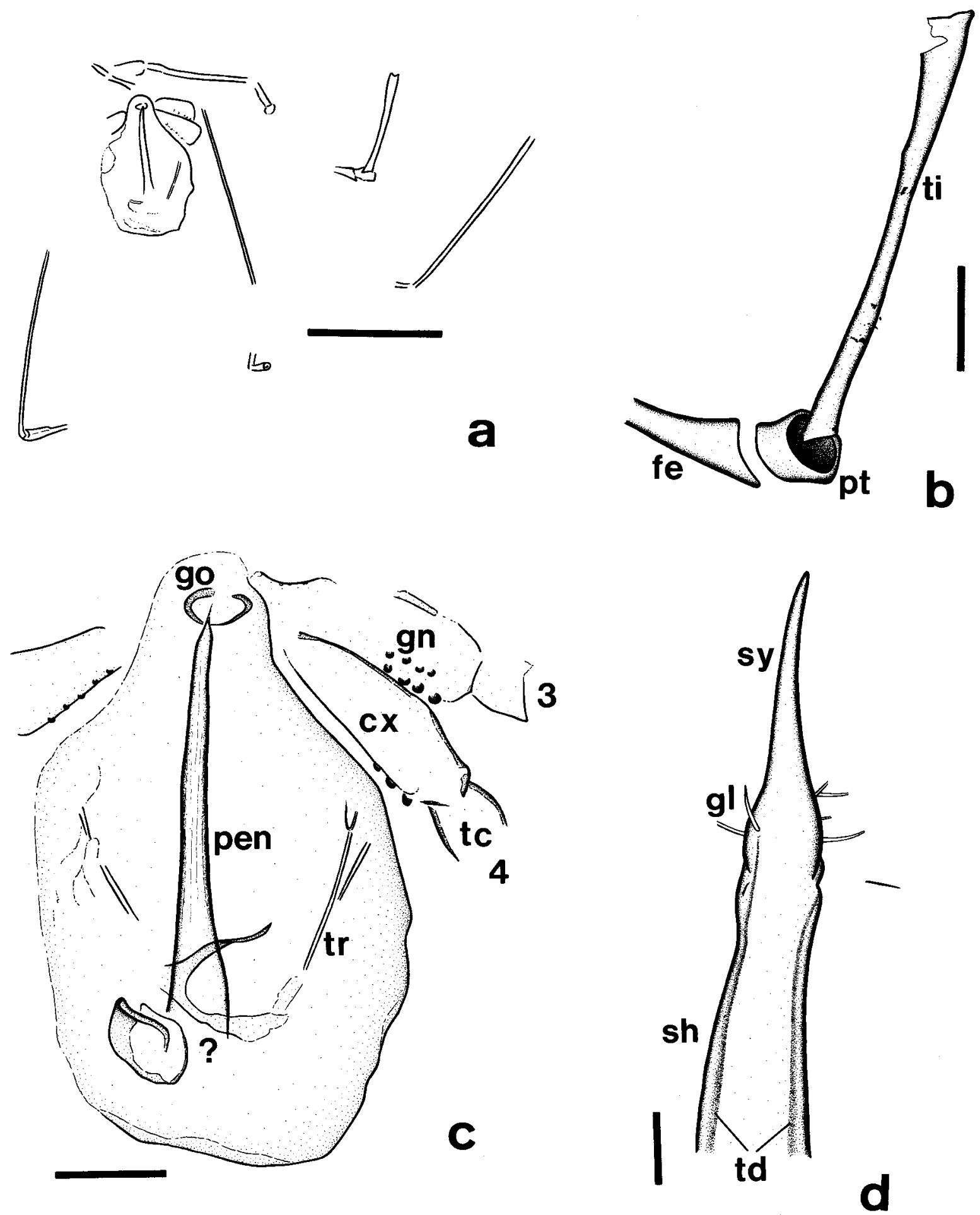

Figure 6 Camera lucida drawings of the specimen shown in Fig. 5: (a) overview (scale bar=1 mm); (b) detail of the leg (scale bar $=200 \mu \mathrm{m}$ ); (c) detail of the body (scale bar $=200 \mu \mathrm{m}$ ); (d) detail of the penis (scale bar $=25 \mu \mathrm{m}$ ). Abbreviations: (cx) coxa; (fe) femur; (gn) coxal granules; (gl) setose glans; (go) gonopore; (pen) penis; (pt) patella; (sh) penis shaft; (sy) stylus; (td) possible tendons of penis musculature; (tc) trochanter; (ti) tibia; (tr) trachea; (3-4) leg numbers; and (?) unidentified cuticular structures.

troguloid Nemastoma lugubre figured by Martens (1976, fig. 8). Like extant troguloids, the penis exhibits a rather simple, acuminate tip with a rather poorly defined glans and only short setae (W. Shear, pers. comm.). With respect to its orientation, the distal curvature of the penis hints that it has been turned slightly on its side. This is unusual compared to living harvestman, where the glans region is never observed turned on its side in this way (J. Martens, pers. comm.). Therefore, taphonomic displacement of the penis during fossilisation may therefore have taken place.

\subsection{PBM 3511 (second male)}

The third specimen (Figs 7, 8) is the least complete, but includes some interesting details. It is essentially a lateral section through the anterior end of the opisthosoma and the prosoma. The opisthosoma contains what looks like a second example of a penis directed towards the inter-coxal gonopore region (Figs 7a \& 8a). Details of the distal end are lacking. The line of section has bisected two or three leg coxae in outline, one of which appears to have ventral tubercles, but the best preserved region is the distal end of the chelicerae. This again 

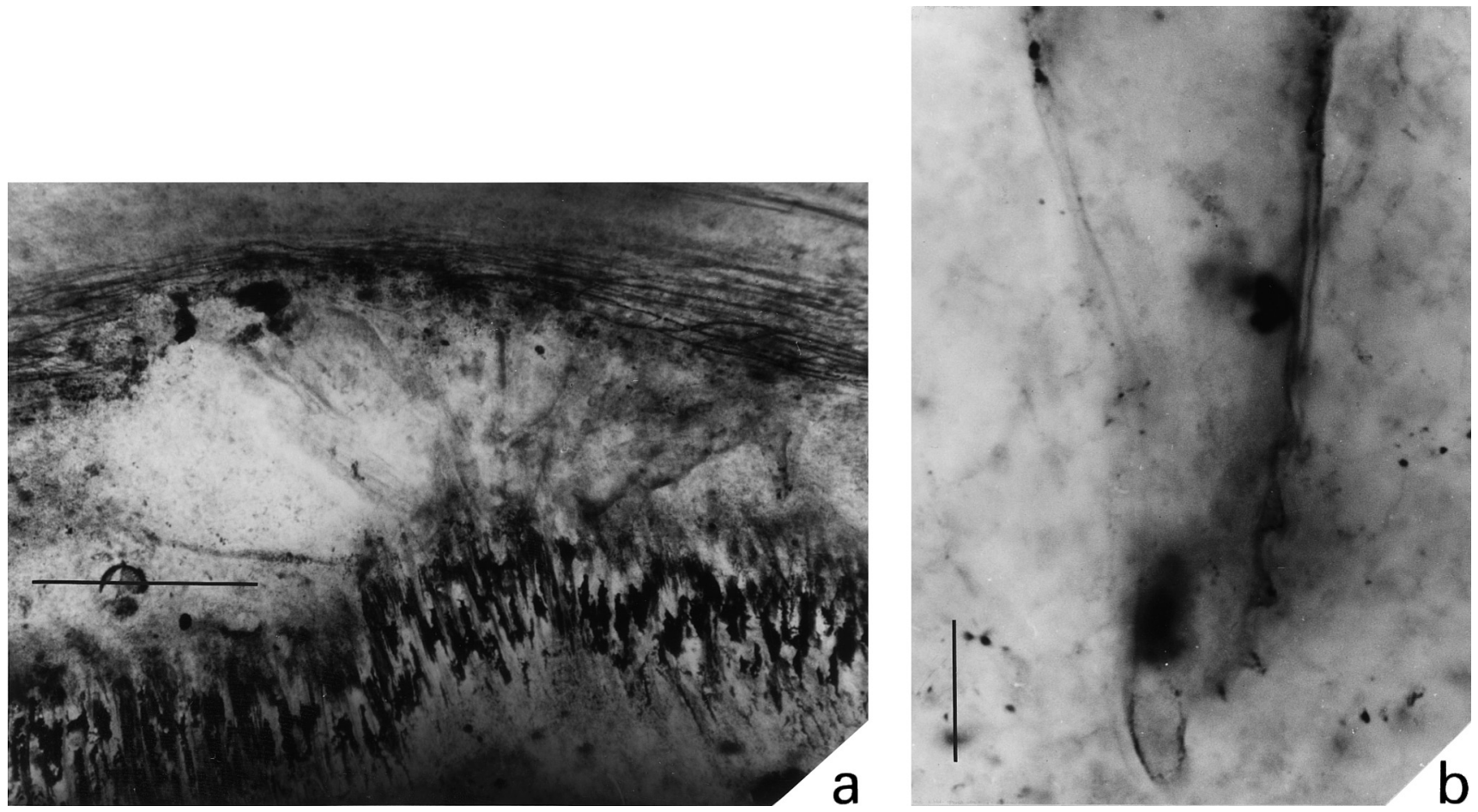

Figure 7 Eophalangium sheari gen. et sp. nov. Paratype 2 (male), slide no. 3511, from the same locality as the holotype. (a). Overview showing a lateral section through the anterior region of the opisthosoma and the coxo-sternal region (scale bar $=500 \mu \mathrm{m}$ ); (b) Detail of the distal end of a chelicera focusing on the terminal dentition on one of the fingers (scale bar $=20 \mu \mathrm{m}$ ).
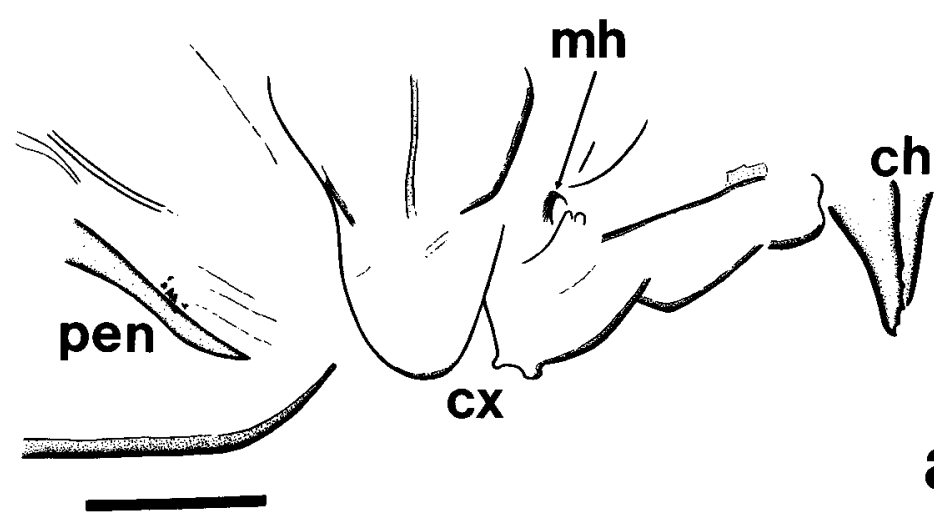

Figure 8 Camera lucida drawings of the specimens shown in Fig. 7: (a) overview (scale bar=250 $\mu \mathrm{m}$ ); (b) detail of the chelicera (scale bar $=20 \mu \mathrm{m}$ ). Abbreviations: (ch) chelicera; (cx) coxae; (de) dentition on free finger; (fif) fixed finger; (frf) free finger; (mh) setose mouthpart element; and (pen) penis.

exhibits a typical harvestman feature with the chelate chelicerae. One finger in particular preserves the distal dentition in great detail (Figs $7 b$ \& 8b) in which up to five individual teeth have been preserved. In comparison to extant taxa, this is probably the distal movable finger of the chela or apotele sensu Shultz (2000), since, the apotele articulates laterally to some degree against the preceding article in both this fossil and in living taxa.

\section{Systematic palaeontology}

\section{Order Opiliones Sundevall, 1833}

Remarks. The referral of our fossils to Opiliones is supported both by the overall habitus of the specimens (compact body with little tagmosis, long and slender legs) and by a unique combination of features: (1) an ovipositor, (2) a penis,
(3) an anteriorly displaced gonopore, (4) a single pair of tracheae and (5) distally dentate chelicerae; for example, see Shultz (1990) for details of characters. Some mites (Acari) also have an ovipositor, but the annulate structure described here is of a type only known thus far from Opiliones (see below).

\section{Suborder Eupnoi Hansen \& Sørenson, 1904}

Remarks. The 'Cyphopalpatores' concept, i.e. [Laniatores (Cyphophthalmi+Palpatores)], developed by Martens (1976, 1978) and co-workers was predominantly based on genital morphology. It has been superseded by recent cladistic analyses in which Shultz (1998) resolved a basic phylogeny of the form [Cyphophthalmi (Palpatores+Laniatores)], while Giribet et al. $(1999,2002)$ recovered \{Cyphophthalmi [Eupnoi (Dyspnoi + Laniatores)]\}. Thus, monophyly of the Palpatores (i.e. eupnoids and dyspnoids) is currently the most contentious 
issue in harvestman higher systematics. The key character for determining the affinities of the Rhynie fossils is the annulate, setose ovipositor (see Section 3.1.4). This highly characteristic morphology is only seen in Cyphophthalmi and Eupnoi (c.f. Martens 1978, figs 36-48; Martens et al. 1981). By contrast, Dyspnoi and Laniatores have a shorter, simpler, non-annulate ovipositor.

This annulate ovipositor was originally used as synapomorphic support for the Cyphopalpatores hypothesis (Shear 1980; Martens et al. 1981). Under parsimony analysis, it resolves as a homoplastic character (e.g. Shultz 1998, fig. 4). With respect to its polarity, Shear (1980) used outgroup comparisons with the short, unsegmented ovipositor of basal Acari to argue that the long, annulate form was apomorphic (see also Martens et al. 1981). Shultz (1998, character 18) scored 'cuticular annuli and setae along shaft' as one of a number of alternative apomorphic states against a plesiomorphic condition of no ovipositor. Giribet et al. (1999, character 33) recognised an unordered state of 'long and segmented', and noted in their discussion that, since the opilionid ovipositor is a unique structure among arachnids, it is difficult to make a priori judgements about the polarity of alternative character states. Therefore, the present authors recognise a good potential apomorphy in the female Rhynie harvestmen (PBM 35013506) that would support its assignment to either Cyphophthalmi or Eupnoi.

The present authors are confident in their referral of this specimen to Eupnoi since its relatively large size $($ c. $6 \mathrm{~mm})$, smooth cuticle and the presence of an optic tubercle on the midline are quite different to Cyphophthalmi, which are generally small (c. $2 \mathrm{~mm}$ ) with highly tuberculate cuticle and which characteristically lack median eyes completely (e.g. Hansen \& Sørenson 1904; Shear 1980). A further diagnostic character of Eupnoi (Giribet et al. 1999, character 21) is the presence of 'two thoracic segments', i.e. the mesopeltidium and metapeltidium. Although this is difficult to resolve unequivocally from a lateral section, this tagmosis pattern does appear to be present in the female (see Section 3.1.1) and further supports eupnoid affinities.

Is the male conspecific? However, if the present authors' interpretation of the penis in the more complete male specimen (PBM 3509) is correct and it really did have two intrinsic muscles, it differs significantly from all modern eupnoids. These have only a single penis muscle and associated tendon (see Section 3.2.4). Therefore, the following possibilities must be considered. It could be that the fossils are not conspecific, and we are dealing with a female eupnoid and an unrelated male with a Nemastoma-like penis belonging, perhaps, to the troguloid (Dyspnoi) lineage. In this scenario, the Rhynie cherts preserve two extant clades and a very early split into the modern major groups is implicit. Unfortunately, PBM 3509 is preserved in a different plane of section to PBM 3503, which does not allow direct comparison of non-genital morphological features. It is noteworthy that the male is only about half the size of the female and the presence of a penis implies maturity. In general, such a substantial difference in size has not been mentioned as a typical secondary sexual characteristic in extant harvestmen (Martens 1978), although Sankey \& Savory (1974) noted that males can have smaller bodies and longer legs.

Alternatively, sensu Martens $(1976,1978)$ and co-workers, there seems to be a general trend to lose penis muscles through harvestman evolution, and the Rhynie fossils could all be (conspecific) eupnoids, but belong to a more basal grade that retained two muscles, the reduction to a single penis muscle occurring in more derived (?extant) eupnoid clades. Despite the attractiveness of this muscle loss hypothesis, Shultz (1998) concluded that the primitive state of the intrinsic penis musculature in harvestmen remains unknown, and that a single step could just as easily transform a one-muscle to a two-muscle state. Thus, we cannot easily resolve whether PBM 3509 preserves an autapomorphy of the Troguloidea or a groundpattern character of the non-cyphophthalmid harvestmen (the Phalangida sensu Giribet et al. 2002). Given this uncertainty, the present authors do not wish to fall into the common trap of assigning different names to different genders, or of naming each partially complete fossil differently. In the absence of further material, they have assumed conspecificity. The female is unequivocally a eupnoid based on its body shape and ovipositor. The male could be as well, albeit with a more plesiomorphic penis morphology, and thus, all the fossils are provisionally assigned to the Eupnoi clade.

\section{Plesion (Genus) Eophalangium gen. nov.}

Diagnosis. Eupnoid harvestman with an optic tubercle at the anterior margin of the carapace, followed by a flat propeltidium that then rises into a distinctly 'hunchbacked' region midway along the length of the body, probably corresponding to the meso- and metapeltidium plus the first opisthosomal tergite.

Derivation of name. From Eo (dawn) and Phalangium, a common, extant genus of long-legged eupnoid harvestman.

Type species. (Only included species) Eophalangium sheari gen. et sp. nov.

Remarks. Eupnoi is currently divided into two extant superfamilies: Phalangoidea (with five families) and Caddoidea (with one family). PBM 3503 is intuitively unlikely to be a caddoid in any sort of modern sense since these small (typically 1-2 mm long) and inconspicuous harvestmen characteristically have enormous eyes occupying much of the propeltidium (Shear 1975). Of the detailed characters which could resolve between these superfamilies (see e.g. Shear 1975; Martens 1978; Giribet et al. 1999), only the presence (Phalangoidea) or absence (Caddoidea) of tracheal spiracles opening on the tibia of the legs can potentially be tested. The present authors found no evidence for tibial spiracles here (Figs $5 \mathrm{~b} \& 6 \mathrm{~b}$ ), but even in extant taxa, these are indistinct and their discovery in the fossils would require a limb podomere in a fortuitous orientation in the matrix. In the absence of further material, the authors regard this character as equivocal and suggest that, given its great age, Eophalangium should be regarded as a plesion genus that potentially resolves at the base of the eupnoid tree, before the modern families became established.

This dorsal morphology with eyes at the front of the carapace and a 'hunchbacked' region is not seen in any of the extant eupnoid harvestmen recorded thus far from Scotland (e.g. Sankey \& Savory 1974) and is further evidence against Crowson's contamination theory (see Section 2.1.4), at least with respect to Recent species.

\section{Eophalangium sheari gen. et sp. nov.} (Figs 1-8)

2003 Devonian harvestman; Dunlop et al., p. 916, fig. 1.

Diagnosis. As for the genus.

Derivation of name. We are pleased to name this important fossil in honour of Professor Bill Shear (Hampden-Sydney College, Virginia, USA) in recognition of his extensive work on both Devonian arachnids and extant harvestmen.

Material. Holotype PBM 3503. Paratypes PBM 3509 \& 3511. Additional material (not figured) PBM 3501-3502 and 3504-3506. All from the Rhynie cherts, Aberdeenshire, Scotland. Early Devonian (Pragian).

Description of PBM 3503. Transverse section of complete female body (Figs 1-4) close to the midline. Body squat and 
compact: total length $5.68 \mathrm{~mm}$; maximum height $2.27 \mathrm{~mm}$. Prosomal dorsal shield length $2.53 \mathrm{~mm}$; pro-, meso- and metapeltidium with respective lengths of $1.41,0.63$ and $0.49 \mathrm{~mm}$. Propeltidium with anteriorly positioned optic tubercle, width $0.29 \mathrm{~mm}$. Propeltidium flat, curving back under the optic tubercle to form a narrow, 0.49-mm, doublure. Prosoma-opisthosoma junction broad with little external tagmosis. Dorsal surface of opisthosoma essentially flat, length $3.15 \mathrm{~mm}$, with slight undulations (?segments). Ventral surface of the opisthosoma deeply bowl-shaped and smooth. Tuberculation or other ornament on body cuticle lacking. Proximal articles of one chelicera preserved in outline, emerging beneath doublure. Chelicera short and fairly robust, total length c. $1.2 \mathrm{~mm}$, but details lacking. Proximal fragment of one pedipalp and two leg coxae preserved behind chelicera.

Opisthosoma contains elongate ovipositor originating deep within the body and running towards the coxal region and presumptive gonopore. Maximum preserved length c. $2 \cdot 4 \mathrm{~mm}$. Width of surrounding membranous sheath c. $0.3 \mathrm{~mm}$, width of actual ovipositor variable along its length, typically c. $0 \cdot 2 \mathrm{~mm}$. Ovipositor annulate along its entire length, annulations fading out anteriorly; (?bifurcate) distal tip not preserved. Annulations c. $50 \mu \mathrm{m}$ wide, formed from deep folds of very thin (c. $1 \mu \mathrm{m}$ ) cuticle. Enclosing sheath also formed from similarly thin, slightly folded cuticle. Ovipositor bears numerous short setae, basal width c. $5 \mu \mathrm{m}$, length $70-90 \mu \mathrm{m}$, originating predominantly on dorsal surface. Ill-defined, dark gut trace lies above ovipositor.

Reverse side of specimen at a more lateral plane of section, restricted to opisthosoma plus more distal outlines of three leg coxae and proximal pedipalp. Opisthosoma contains extensive tracheal system. Tracheae originate behind fourth leg coxa, but actual spiracle indistinct. Large primary trachea, maximum diameter c. $170 \mu \mathrm{m}$, curves anteriorly and narrows slightly to c. $130 \mu \mathrm{m}$ as it enters the prosoma. At least nine smaller tracheae branch off the primary trachea. Proximal parts of primary and some secondary tracheae with ring-like thickenings of the cuticle. Four large secondary tracheae branch off basal region of proximal trachea; secondary tracheae diameters c. $40-55 \mu \mathrm{m}$. All secondary tracheae run postero-laterally at an angle of about $45^{\circ}$ within the opisthosoma. Almost $2 \mathrm{~mm}$ of secondary tracheae preserved in total, dividing into at least 12 smaller branches around the gut trace. Midgut preserved as thick, bag-like tube, maximum width $0.44 \mathrm{~mm}$. Presumptive anterior area poorly defined, but posterior area more regular, becoming narrower posteriorly. Narrow, c. $70 \mu \mathrm{m}$ diameter, hindgut curves down towards anus. Anal region slightly swollen in appearance.

Description of PBM 3509. Partially complete male (Figs 5, 6) in ventral view. Segmentation indistinct. Opisthosoma approximately oval in outline, but coming to a blunt point anteriorly, bearing a sclerotised, ring-like gonopore; width $0.13 \mathrm{~mm}$. Length of opisthosoma $1.16 \mathrm{~mm}$; maximum width $0.68 \mathrm{~mm}$. Opisthosoma contains a pair of faint (?secondary) tracheal branches, length up to c. $0.4 \mathrm{~mm}$, originating behind the fourth pair of leg coxae and running medio-posteriorly. Towards the posterior end, opisthosoma contains some illdefined sclerotised elements of uncertain affinity, possibly associated with the basal region of the penis. Penis with a total length of c. $0.8 \mathrm{~mm}$, consisting of a slender, rod-shaped shaft, basal width $120 \mu \mathrm{m}$, positioned on the midline and tapering anteriorly towards the gonopore; distal width $26 \mu \mathrm{m}$. A pair of dark, lateral lineations (?muscle tendons), width $2 \mu \mathrm{m}$, run within shaft and attach at the base of the distal glans. Shaft widens slightly at articulation point with the glans. Glans itself oval, length c. $35 \mu \mathrm{m}$, width $26 \mu \mathrm{m}$, slightly swollen, bearing at least five or six short, up to $15 \mu \mathrm{m}$, setae. Glans merges distally into bluntly pointed stylus, length $70 \mu \mathrm{m}$, containing slender lumen.

Coxae of legs 3 and 4 preserved as subtriangular elements surrounding gonopore region. Coxae bear one or two rows of four or five highly sclerotised tubercles. Adjacent trochanters short, quadrate in outline. Right leg 3 preserved in situ; other legs somewhat disarticulated. All legs very long and slender with elongate femora and tibiae which widen both proximally and distally. Patellae of all legs correspondingly very short. Right leg 3 most complete, with podomere lengths (in millimetres) of: coxa $0 \cdot 44$, trochanter $0 \cdot 13$, femur $1 \cdot 15$, patella $0 \cdot 07$ and tibia $0 \cdot 70$. More distal podomeres not preserved. Other disarticulated legs with tibia lengths of at least $1.5 \mathrm{~mm}$. Legs lack setae or other ornamentation.

Description of PBM 3511. Lateral section of incomplete male (Figs 7, 8) showing anterior part of opisthosoma, some leg coxae and trochanters, and chelicerae; total preserved length ca. $1.7 \mathrm{~mm}$. Opisthosoma contains distal end of smooth, tapering penis angled down at c. $45^{\circ}$ towards gonopore region; details lacking. Proximal leg podomeres preserved in outline only, at least one preserving ventral tuberculation. Chelicera almost complete; length ca. $0.7 \mathrm{~mm}$. Distal article (apotele) particularly well preserved. Wider and slightly bulbous proximally, but curving and narrowing to a bluntly rounded and slightly incurving tip. Five triangular teeth, three proximal ones quite broad, two distal ones sharper and more pointed, on the distal, mesal margin of the apotele. Focusing through the specimen suggests corresponding teeth occur on the fixed finger of the chela.

\section{Discussion}

The absence of pre-Carboniferous harvestmen was always an anomaly in the fossil record since other diverse arachnid orders, like spiders, scorpions, mites and pseudoscorpions, are known from the Mid-Silurian to Mid-Devonian. Scorpions go back to the Silurian (Llandovery) and may have been aquatic at this time (Jeram 1998). As Selden (1993) pointed out, current phylogenies (Shultz 1990; Giribet et al. 2002) predict the occurrence of, possibly aquatic, harvestmen or their stem lineage in the Early to Mid Silurian through their putative relationship with scorpions. Hypotheses about the origins of modern harvestmen are difficult to test. Unlike scorpions (Jeram 1998), for example, there is no stem lineage for Opiliones showing the accumulation of autapomorphies towards the crown-group. Despite its Early Devonian age, Eophalangium sheari preserves almost all the major morphological apomorphies which define living Opiliones, i.e. a penis, an ovipositor and a single pair of tracheae. Only the openings of the repugnatorial glands are lacking in the Rhynie fossils, and even these are equivocal because of the absence of an appropriate plane of section rather than being clearly absent.

\subsection{Crown-groups, stasis and cladogenesis}

Eophalangium sheari can be referred to an extant suborder (see Section 4), and thus, represents a crown-group harvestman. This is a significant observation because, among other chelicerates, only mites (Hirst 1923) and pycnogonids (Bergström et al. 1980) also have a crown-group fossil record extending back as far as the Early Devonian. The oldest (crown-group) pseudoscorpion appears in the Middle Devonian (Shear et al. 1989). Unequivocal members of extant lineages of scorpions (Jeram 1998) and xiphosurans (Anderson \& Selden 1997) currently go back only to the Early Carboniferous, and spiders (Selden 1996) to the Late Carboniferous. A corollary of this is that long-legged harvestmen exhibit an extraordinary degree of 
morphological stasis, even down to fine details of their genitalia and respiratory organs. This is despite the fact that harvestmen are somewhat generalist and widespread, and do not appear to occupy specialist niches or habitats which would insulate them from major selective pressures, such as the rise of the insects or the appearance of terrestrial vertebrate predators. In this context, the co-occurrence of similarly modern-looking fossil collembollans, myriapods and mites is interesting. If one were to substitute spiders for the extinct trigonotarbids, the Rhynie chert yields many of the animal types which still characterise a modern leaf-litter environment and this detritivore-predator 'litter community' may reflect one of the most ancient terrestrial ecosystems.

Eophalangium sheari also provides minimum divergence times of c. $400 \mathrm{Ma}$ for the alternative eupnoid sister group relationships proposed in the literature (see Section 4). In Shultz's \{Cyphophthalmi [Laniatores (Eupnoi+Dyspnoi)]\} scheme, all four major lineages are predicted to occur in some form in the Early Devonian. By contrast, in Giribet et al.'s \{Cyphophthalmi [Euponi (Dyspnoi+Laniatores)]\} hypothesis, the cyphophthalmid, eupnoid and so-called Dyspnolaniatores clade are all predicted to be present in the Early Devonian, but the differentiation into dyspnoids and Laniatores would be constrained to the Late Carboniferous by the occurrence of the oldest putative dyspnoid, Eotrogulus fayoli Thevenin, 1901. If the Rhynie males can be shown to be dyspnoids (see Section 4), then a Devonian origin for all four major lineages is again predicted, irrespective of which phylogeny is correct.

\subsection{The oldest tracheal tubes}

For many years, the book lungs reported in the Rhynie trigonotarbid arachnids by Claridge \& Lyon (1961) have been the oldest unequivocal evidence in any animal for terrestrial respiration. Terrestrial animal life was pushed back even further by the tracheal spiracles recently described in a MidSilurian millipede by Wilson \& Anderson (2004). The tracheae (see Section 3.1.5) described here in Eophalangium sheari are the oldest record of actual tracheal tubes and represent the oldest record of tracheal respiration in arachnids. These fossilised tracheae would have relied on diffusion of air over several millimetres and are wholly inappropriate for gas exchange in water. Their presence overwhelmingly suggests that the Rhynie harvestmen were fully terrestrial too and the tracheal preservation is a result of the unique taphonomic conditions at Rhynie. Tracheae occur in a variety of groups (insects, millipedes, centipedes, symphylans, some pauropods and some arachnids) and the detailed investigations of Hilken (1998) clearly demonstrated that they are a homoplastic character that has arisen a number of times in arthropods in response to life on land. Different arthropod taxa may have evolved their tracheae at different times and the present authors can now confirm that this occurred by at least the Early Devonian for the arachnids. The Rhynie mites (Hirst 1923) belong to the so-called prostigmatid group, which, as their name suggests, would be expected to have tracheae opening in the anterior half of the body. This has yet to be confirmed from available fossil material.

\subsection{Palaeobiology}

Eophalangium sheari is a new addition to the Rhynie fauna and supports the general impression of a lakeside ecosystem with a flourishing terrestrial arthropod community living among the early vascular plants. On present evidence, E. sheari appears to have been much rarer than the mites or trigonotarbids, both of which are now known from hundreds of specimens or fragments when taking into account unpublished material (pers. obs.; Steve Fayers, pers. comm.). The overall similarity of the present fossils to extant harvestmen suggests a similar mode of life. Eophalangium sheari can be envisaged as a moderately large (c. $6 \mathrm{~mm}$ body length), long-legged animal clambering in a somewhat ungainly fashion among stands of Aglaophyton. The authors suspect that it was a predator on other, smaller arthropods, probably supplementing its diet by scavenging and/or facultative omnivory. The presence of the penis/ ovipositor complex allows further behavioural inferences to be made. The anteriorly directed penis is the oldest record of such an organ from a terrestrial animal (for an older aquatic example, see Siveter et al. 2003). The harvestman penis offers a method of direct sperm transfer, something again consistent with a terrestrial animal. It implies that $E$. sheari copulated in the same face-to-face manner described for living taxa (e.g. Henking 1888). The annulated ovipositor of Recent female eupnoids can be extended some considerable distance beyond the body (Henking 1888) and is typically used to lay the eggs protectively among plant litter or within the substrate. This behaviour seems likely for E. sheari, and coupled with the modernity of the respiratory system, it suggests that much of the gross morphology and reproductive biology of eupnoid harvestmen has remained fundamentally unchanged for at least 400 million years.

\section{Acknowledgements}

We are grateful to the organisers of the Rhynie Hot Spring System conference for inviting this contribution, and Gonzalo Giribet, Christian Komposch, Jochen Martens, Jürgen Gruber and Steve Fayers for valuable comments on the material. Paul Selden, Greg Edgecombe, Bill Shear and Nigel Trewin are thanked for helpful criticisms of an earlier draft of the text.

\section{References}

Anderson, L. I. \& Selden, P. A. 1997. Opisthosomal fusion and phylogeny of Palaeozoic Xiphosura. Lethaia 30, 19-31.

Anderson, L. I. \& Trewin, N. H. 2003. An Early Devonian arthropod fauna from the Windyfield cherts, Aberdeenshire, Scotland. Palaeontology 46, 467-509.

Beall, B. S. 1997. Arachnida. In Shabica, W. \& Hay, A. A. (eds). Richardson's Guide to the Fossil Fauna of Mazon Creek, 140-54. Chicago, Illinois: Northeastern Illinois University.

Bergström, J., Stürmer, W. \& Winter, G. 1980. Palaeoisopus, Palaeopantopus and Palaeothea, pycnogonid arthropods from the Lower Devonian Hunsrück Slate, West Germany. Paläontologische Zeitschrift 54, 7-54.

Claridge, M. F. \& Lyon, A. G. 1961. Lung books in the Devonian Palaeocharinidae (Arachnida). Nature 191, 1190-1.

Cokendolpher, J. C. 1986. A new species of fossil Pellobunus from Dominican Republic amber (Arachnida: Opiliones: Phalangodidae). Caribbean Journal of Science 22, 205-11.

Cokendolpher, J. C. \& Poinar, G. O. Jr., 1998. A new fossil harvestman from Dominican Republic amber (Opiliones, Samoidae, Hummelinckiolus). Journal of Arachnology 26, 9-13.

Crowson, R. A. 1985. Comments on Insecta of the Rhynie Chert. Entomologica Generalis 11, 97-8.

Dunlop, J. A. 1994. Filtration mechanisms in the mouthparts of tetrapulmonate arachnids (Trigonotarbida, Araneae, Amblypygi, Uropygi, Schizomida). Bulletin of the British Arachnological Society 9, 267-73.

Dunlop, J. A., Anderson, L. I., Kerp, H. \& Hass, H. 2003. Preserved organs of Devonian harvestmen. Nature 425, 916.

Dunlop, J. A. \& Giribet, G. 2003. The first fossil cyphophthalmid (Arachnida: Opiliones) from Bitterfeld amber, Germany. Journal of Arachnology 31, 371-8.

Giribet, G. 2000. Catalogue of the Cyphophthalmi of the world. Revista Ibérica de Arachnología 2, 49-76.

Giribet, G., Rambla, M., Carranza, S., Bagunà, J., Riutort, M. \& Ribera, C. 1999. Phylogeny of the arachnid order Opiliones (Arthropoda) inferred from a combined approach of complete 
$18 \mathrm{~S}$ and partial 28S ribosomal DNA sequences and morphology. Molecular Phylogenetics and Evolution 11, 296-307.

Giribet, G., Edgecombe, G. D., Wheeler, W. C. \& Babbitt, C. 2002. Phylogeny and systematic position of Opiliones: a combined analysis of chelicerate relationships using morphological and molecular data. Cladistics 18, 5-70.

Greenslade, P. M. J. 1988. Reply to A. A. Crowson's 'Comments on Insecta of the Rhynie Chert' (1985 Entomol. Gener. 11(1/2): 097-098). Entomologica Generalis 13, 115-17.

Hansen, H. J. \& Sørensen, W. 1904. On two orders of Arachnida. Cambridge: Cambridge University Press.

Hilken, G. 1998. Vergleich von Tracheensystemen unter phylogenetische Aspekt. Verhandlungen des Naturwissenschaftlichen Vereins in Hamburg (NF) 37, 5-94.

Hirst, S. 1923. On some arachnid remains from the Old Red Sandstone (Rhynie Chert bed, Aberdeenshire). Annals and Magazine of Natural History 12 (9), 455-74.

Hirst, S. \& Maulik, S. 1926. On some arthropod remains from the Rhynie Chert (Old Red Sandstone). Geological Magazine 63, $69-71$.

Höfer, A. M., Perry, S. F. \& Schmitz, A. 2000. Respiratory system of arachnids II: morphology of the tracheal system of Leiobunum rotundum and Nemastoma lugubre (Arachnida, Opiliones). Arthropod Structure and Development 29, 13-21.

Henking, H. 1888. Biologische Beobachtungen an Phalangiden. Zoologischen Jahrbüchern, Systematik 3, 319-35.

Jell, P. A. \& Duncan, P. M. 1986. Invertebrates, mainly insects, from the freshwater Lower Cretaceous Koonwarra Fossil Bed (Korumburra Group), South Gippsland, Victoria. Memoirs of the Association of Australasian Palaeontologists 3, 111-205.

Jeram, A. J. 1998. Phylogeny, classification and evolution of Silurian and Devonian scorpions. In Selden, P. A. (ed.) Proceedings of the 17th European Colloquium of Arachnology, Edinburgh 1997, 1731. Burnham Beeches: The British Arachnological Society.

Kaestner, A. 1933. Verdauungs- und Atemorgane der Weberknechte Opilio parietinus de Geer und Phalangium opilio L. Zeitschrift für Morphologie und Ökologie der Tiere 27, 587-623.

Kaestner, A. 1941. Ordnung der Arachnida: Opiliones Sundevall =Weberknechte. In Krumbach, T. (ed.) Handbuch der Zoologie, Band 3 (2), Chelicerata, 300-93. Berlin: Walter de Gruyter and Co.

Kelman, R., Feist, M., Trewin, N. \& Hass, H. 2004. Charophyte algae from the Rhynie chert. Transactions of the Royal Society of Edinburgh: Earth Sciences 94 (for 2003), 445-55.

Kury, A. B. 2003. Annotated catalogue of the Laniatores of the New World (Arachnida, Opiliones). Revista Ibérica de Aracnología Volumen especial monográfico no. 1.

Martens, J. 1976. Genitalmorphologie, System und Phylogenie der Weberknechte (Arachnida: Opiliones). Entomologica Germanica 3, 51-58.

Martens, J. 1978. Spinnentiere, Arachnida, Weberknechte, Opiliones. Die Tierwelt Deutschlands. 64. Teil. Jena: Gustav Fischer.

Martens, J., Hoheisel, U. \& Götze, M. 1981. Vergleichende Anatomie der Legeröhren der Opiliones als Beitrag zur Phylogenie der Ordnung (Arachnida). Zoologische Jahrbücher, Anatomie 105, $13-76$.

Peters, R. 1966a. Weberknechte. I. Anatomische Übersicht. Histologie der Verdauungsorgane. Mikrokosmos 7, 208-13.

Peters, R. 1966b. Weberknechte. II. Histologie: Kutikula, Stinkdrüsen, Blut, Excretionsorgane, Geschlectsorgane. Mikrokosmos 8, 240-6.

Petrunkevitch, A. I. 1913. A monograph of the terrestrial Palaeozoic Arachnida of North America. Transactions of the Connecticut Academy of Arts and Science 18, 1-137.

Petrunkevitch, A. I. 1955. Arachnida. In Moore, R. C. (ed.) Treatise on Invertebrate Palaeontology, Part $P$, Arthropoda 2, 42-162.
Boulder, Colorado and Lawrence, Kansas: Geological Society of America and University of Kansas Press.

Rambla, M. 1975. Los Opiliones (Arachnida) (2.a parte). Graellsia 30, $187-200$

Rice, C. M., Trewin, N. H. \& Anderson, L. I. 2002. Geological setting of the Early Devonian Rhynie cherts, Aberdeenshire, Scotland: an early terrestrial hot-spring system. Journal of the Geological Society, London 159, 203-14.

Roewer, C.-F. 1923. Die Weberknechte der Erde. Jena: Gustav Fischer.

Roger, J. 1946. Résultates scientifiques de la mission C. Arambourg en Syrie et en Iran (1938-39). Les Invertébrés des Couches à Poissons du Crétacé supérieur du Liban-2étude Palébiologique des gisements. Mémoires de la Société Géologique de France, Palaéontologie 51, 60-4.

Rößler, R., Dunlop, J. A. \& Schneider, J. 2003. A redescription of some poorly known Rotliegend arachnids from the Lower Permian (Asselian) of the Ilfeld and Saale Basins, Germany. Paläontologisches Zeitschrift 77, 417-27.

Rühm, J. 1926. Über die Nahrung von Phalangium L. Zoologischer Anzeiger 68, 154-8.

Sankey, J. H. P. \& Savory, T. H. 1974. British Harvestmen. Synopses of the British Fauna (New Series), No. 4. London: Academic Press.

Scourfield, D. J. 1926. On a new type of crustacean from the Old Red Sandstone. Philosophical Transactions of the Royal Society of London, Series B 214, 153-87.

Selden, P. A. 1993. Fossil arachnids - recent advances and future prospects. Memoirs of the Queensland Museum 33, 389-400.

Selden, P. A. 1996. First fossil mesothele spider, from the Carboniferous of France. Revue suisse de Zoologie hors série, 585-96.

Shear, W. A. 1975. The opilionid family Caddidae in North America, with notes on species from other regions (Opiliones, Palpatores, Caddoidea). Journal of Arachnology 2, 65-88.

Shear, W. A. 1980. A review of the Cyphophthalmi of the United States and Mexico, with a proposed reclassification of the suborder (Arachnida, Opiliones). American Museum Novitates 2705, $1-34$.

Shear, W. A. Schwaller, W. \& Bonamo, P. M. 1989. Record of Palaeozoic pseudoscorpions. Nature 341, 527-9.

Shultz, J. W. 1990. Evolutionary morphology and phylogeny of Arachnida. Cladistics 6, 1-38.

Shultz, J. W. 1998. Phylogeny of Opiliones (Arachnida): an assessment of the 'Cyphopalpatores' concept. Journal of Arachnology 26, $257-72$.

Shultz, J. W. 2000. Skeletomuscular anatomy of the harvestman Leiobunum aldrichi (Weed, 1893) (Arachnida: Opiliones: Palpatores) and its evolutionary significance. Zoological Journal of the Linnean Society 128, 401-38.

Siveter, D. J., Sutton, M. D., Briggs, D. E. G. \& Siveter, D. J. 2003. An ostracode crustacean with soft parts from the Lower Silurian. Science 302, 1749-51

Starega, W. 2002. Baltic amber harvestmen (Opiliones) from Polish collections. Annales Zoologici 52, 601-4.

Sundevall, J. C. 1833. Conspectus Arachnidum. Londini Gothorum. Typus Excudit C. F. Berling. London: Universitas Typographus.

Thevenin, A. 1901. Sur la découverte d'arachnides dans le terrain houiller de Commentry. Bulletin de la Société Géologique de France, Quatrième Série 1, 605-11.

Wilson, H. M. \& Anderson, L. I. 2004. Morphology and taxonomy of Paleozoic millipedes (Diplopoda: Chilognatha: Archipolypoda) from Scotland. Journal of Paleontology 78, 169-84.

Wood, S. P., Panchen, A. L. \& Smithson, T. R. 1985, A terrestrial fauna from the Scottish Lower Carboniferous. Nature 314, 355-6.

JASON A. DUNLOP, Institut für Systematische Zoologie, Museum für Naturkunde der HumboldtUniversität zu Berlin, Invalidenstraße 43, D-10115 Berlin, Germany. e-mail: jason.dunlop@museum.hu-berlin.de

LYALL I ANDERSON, Department of Geology \& Zoology, National Museums of Scotland, Chambers Street, Edinburgh, EH1 1JF, UK.

e-mail: 1.anderson@nms.ac.uk

HANS KERP and HAGEN HASS, Forschungsstelle für Paläobotanik, Westfälische WilhelmsUniversität, Hindenburgplatz 57, D-48143 Münster, Germany.

e-mail: kerp@uni-muenster.de

MS received 17 September 2003. Accepted for publication 10 June 2004. 